\title{
Muscle gene electrotransfer is increased by the antioxidant tempol in mice
}

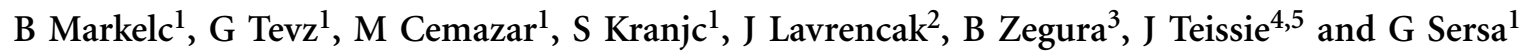

Electropermeabilization (EP) is an effective method of gene transfer into different tissues. During EP, reactive oxygen species (ROS) are formed, which could affect transfection efficiency. The role of generated ROS and the role of antioxidants in electrotransfer in myoblasts in vitro and in Musculus tibialis cranialis in mice were, therefore, investigated. We demonstrate in the study that during EP of $\mathrm{C} 2 \mathrm{C} 12$ myoblasts, ROS are generated on the surface of the cells, which do not induce long-term genomic DNA damage. Plasmid DNA for transfection (pEGFP-N1), which is present outside the cells during EP, neutralizes the generated ROS. The ROS generation is proportional to the amplitude of the electric pulses and can be scavenged by antioxidants, such as vitamin $\mathrm{C}$ or tempol. When antioxidants were used during gene electrotransfer, the transfection efficiency of $\mathrm{C} 2 \mathrm{C} 12$ myoblasts was statistically significantly increased 1.6-fold with tempol. Also in vivo, the transfection efficiency of M. tibialis cranialis in mice was statistically significantly increased 1.4 -fold by tempol. The study indicates that ROS are generated on cells during EP and can be scavenged by antioxidants. Specifically, tempol can be used to improve gene electrotransfer into the muscle and possibly also to other tissues.

Gene Therapy (2012) 19, 312-320; doi:10.1038/gt.2011.97; published online 30 June 2011

Keywords: electropermeabilization; gene electrotransfer; muscle; tempol; reactive oxygen species

\section{INTRODUCTION}

Electropermeabilization (EP) is a physical method that enables the introduction of molecules such as dyes, drugs or genetic material into cells. By applying external electric field pulses to living cells, a local increase in transmembrane potential difference occurs. Under welldefined conditions, the membrane becomes transiently permeabilized, which enables various molecules to enter the cell. ${ }^{1,2}$

EP is currently in clinical use for the delivery of cancer chemotherapeutic drugs such as bleomycin or cisplatin (electrochemotherapy) in the treatment of skin metastases or deep-seated tumors. ${ }^{3-5}$ Complete responses of skin metastases, predominantly melanoma, are in the range of $70-80 \%{ }^{6}$

EP was originally discovered for the delivery of plasmid DNA into cells in vitro by Neumann et al. in 1982. ${ }^{7}$ Since the first report of successful gene electrotransfection of the skin, ${ }^{8}$ the method has been increasingly used for the delivery of different types of DNA/RNA molecules into cells in vitro and different tissues, including muscle and tumors in vivo. ${ }^{9-19}$ Furthermore, gene electrotransfer has also proved to be safe and effective in the treatment of cancer. A report on the first clinical study of gene electrotransfer, which used therapeutic gene coding for interleukin-12 for the treatment of metastatic melanoma, has already been published by Daud et al. ${ }^{20}$ There are also other clinical studies in progress on muscle tissue for DNA vaccination, systemic delivery of therapeutic proteins and correction of gene defects in muscles; therefore, the studies on muscle cell cultures and muscle tissue are of special importance. Namely, good correlation between the in vitro studies on $\mathrm{C} 2 \mathrm{C} 12$ cells and in vivo studies on muscle tissue has been demonstrated. ${ }^{21,22}$ In addition, gene therapy studies are on-going in veterinary medicine, showing that the field is rapidly expanding. ${ }^{23-26}$

Although EP has many advantages compared with viral transfection methods, such as the lack of immunogenicity, ease of preparation of large quantities of endotoxin-free plasmid DNA, control and reproducibility of the method and the availability of electropulsators approved for clinical use, there are some problems that must be resolved before the method can become widely used.9,23 The main problem is still the low expression efficiency of gene electrotransfer in different tissues. Several attempts have, therefore, been made to improve transfection efficiency, determination of appropriate pulse parameters for specific tissue, the interval between plasmid injection and the application of electric pulses for a specific tumor type and degradation of tumor extracellular matrix. ${ }^{15,27-32}$ In addition, numerical modeling was used to further increase the efficacy of electrogene transfer in muscle tissue. ${ }^{33}$

Previous reports have indicated that EP induces the generation of reactive oxygen species (ROS), mainly ${ }^{\bullet} \mathrm{O}_{2}{ }^{-}$, which are generated on the permeabilized part of the cell membrane during $\mathrm{EP}^{34}$ only when the cells are reversibly permeabilized. These ROS can damage lipids, proteins and DNA and, consequently, effect long-term cell survival. In addition to that, there have been several studies reporting the induction of genes for radical scavenging molecules after EP. ${ }^{35-37}$ The generation of ROS and their effect on cell survival after EP can be avoided by adding antioxidant ascorbic acid, ${ }^{38,39}$ but the toxicity of the compound alone is too high for safe usage in vivo. The impact of generated ROS on gene electrotransfer is still not clear.

\footnotetext{
${ }^{1}$ Department of Experimental Oncology, Institute of Oncology Ljubljana, Ljubljana, Slovenia; ${ }^{2}$ Department of Cytopathology, Institute of Oncology Ljubljana, Ljubljana, Slovenia; ${ }^{3}$ Department of Genetic Toxicology and Cancer Biology, National Institute of Biology, Ljubljana, Slovenia; ${ }^{4}$ IPBS CNRS, UMR 5089, Toulouse Cedex, France and ${ }^{5}$ Université de Toulouse; UPS, IPBS, Toulouse, France

Correspondence: Dr J Teissie, IPBS CNRS, UMR 5089, 205 Route de Narbonne, F-31077 Toulouse Cedex, France and Dr G Sersa, Department of Experimental Oncology, Institute of Oncology Ljubljana, Zaloska cesta 2, Ljubljana SI-1000, Slovenia.

E-mails: justin.teissie@ipbs.fr and gsersa@onko-i.si

Received 21 February 2011; revised 13 May 2011; accepted 16 May 2011; published online 30 June 2011
} 


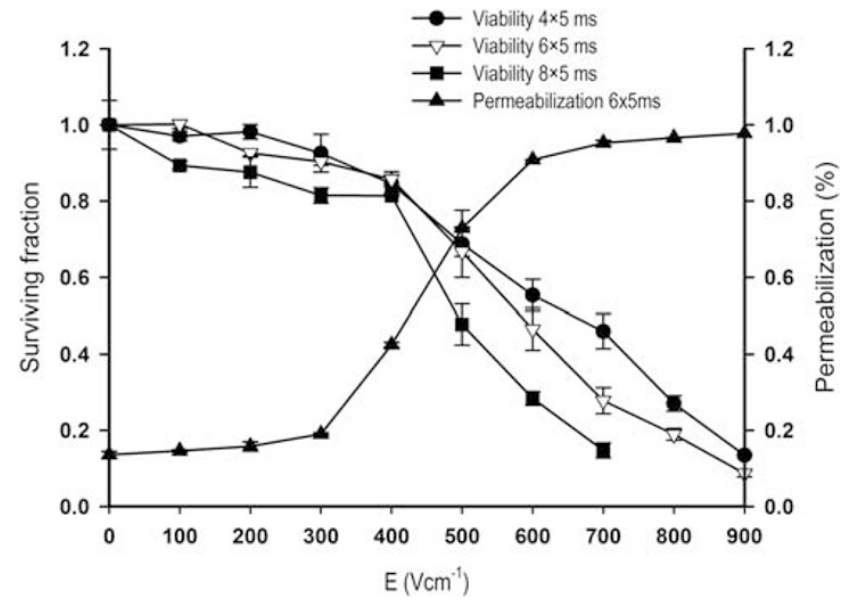

Figure 1 Cell survival and permeabilization of $\mathrm{C} 2 \mathrm{C} 12$ cells after EP. Survival and permeabilization curves of the cells treated with different number of pulses at different amplitude per distance ratios, $5 \mathrm{~ms}$ duration and $1 \mathrm{~Hz}$ repetition frequency are presented.

The aim of our study was, therefore, to explore the generation of ROS by the exposure of cells to electric pulses used for electrogene therapy. In relation to this, the effect of ROS scavengers on the transfection efficiency of electrotransfer of plasmid DNA encoding green fluorescent protein (GFP) to $\mathrm{C} 2 \mathrm{C} 12$ myoblasts in vitro and Musculus tibialis cranialis in mice was tested, as a model system. The results may be indicative for other tissues that could benefit from increased transfection efficiency; predominantly tumors.

\section{RESULTS}

$\mathrm{EP}$ and survival of $\mathrm{C} 2 \mathrm{C} 12$ mouse myoblasts

Cell survival and permeabilization of $\mathrm{C} 2 \mathrm{C} 12$ cells in vitro were determined for different electric pulse parameters: ranging from 4 to 8 electric pulses of $5 \mathrm{~ms}$ duration of various amplitudes (Figure 1). The results indicated that better cell survival of cells was obtained with 4 or 6 electric pulses than with 8 electric pulses. Furthermore, there was no difference in cell survival between 4 and 6 electric pulses at $500 \mathrm{Vcm}^{-1}$, whereby cell permeabilization was $\sim 70 \%$, which is the amplitude of electric pulses that was selected for further experiments.

\section{EP-induced ROS generation on cells and neutralizing effect of plasmid DNA}

The generation of ROS was determined by lucigenin chemiluminescence, which is indicative of ROS generated outside of cells. ${ }^{34}$ An increase in ROS generation was detected in the range of electric pulse amplitude starting at 300 up to $800 \mathrm{Vcm}^{-1}$. Up to $500 \mathrm{Vcm}^{-1}$, a steady increase in ROS generation was detected, which reached a 25-fold increase compared with the untreated control group (Figure 2a). At higher amplitudes, a slight decrease in ROS generation was observed. From our previous results, this appears to be due to decreased cell viability and damaging effects of EP on cells. ${ }^{38}$

The generated ROS were neutralized by the addition of plasmid DNA (pEGFP-N1) into the cells' suspension prior to the EP of cells. In the presence of plasmid DNA, the chemiluminescence intensity was significantly reduced at all amplitudes of electric pulses tested (Figure 2a). There was a trend to less efficient ROS scavenging at the highest amplitudes of electric pulses tested, during which the cell
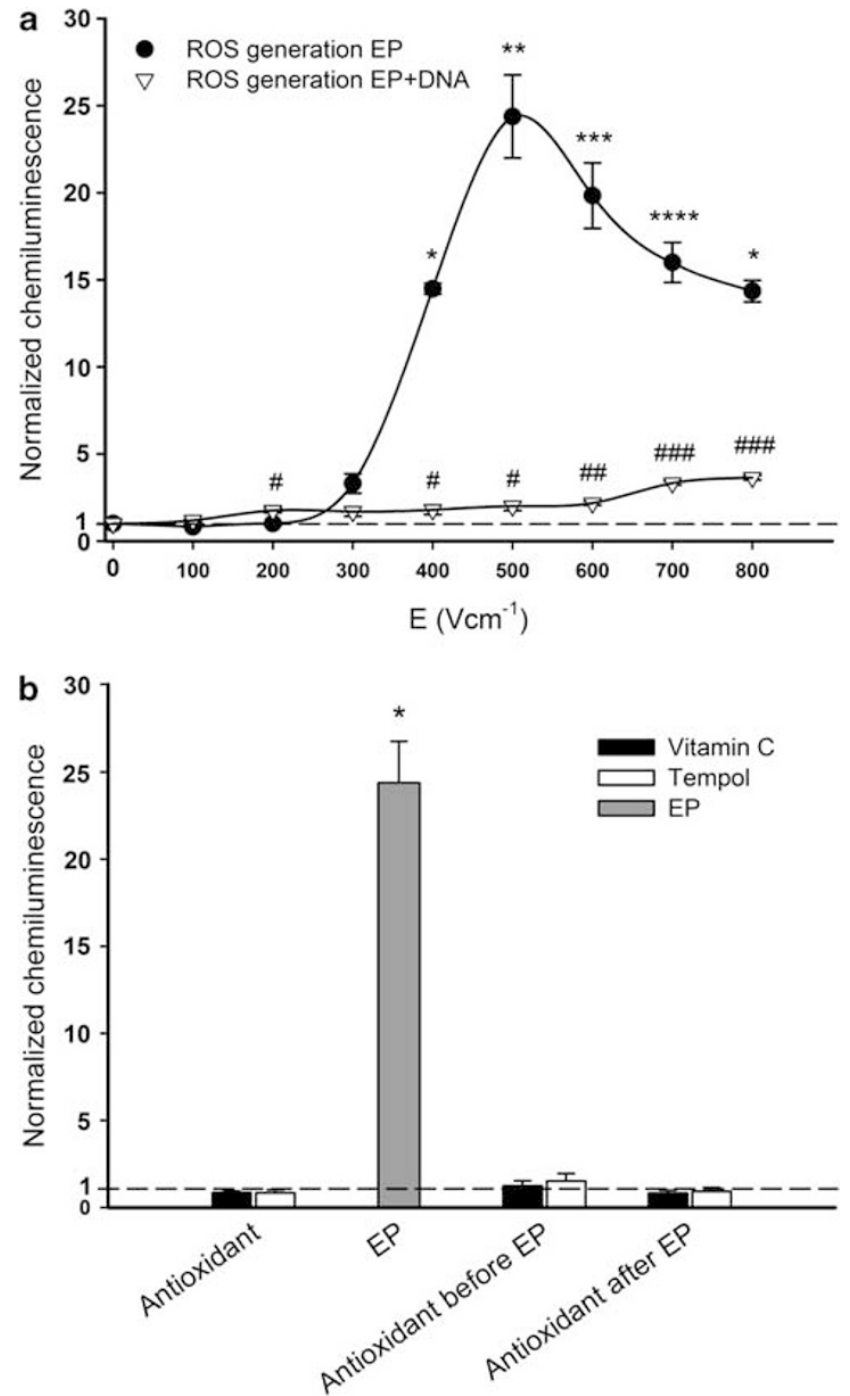

Figure 2 EP-induced ROS on $\mathrm{C} 2 \mathrm{C} 12$ cells which are scavenged by plasmid DNA (pEGFP-N1) or antioxidants (tempol, vitamin C). Lucigenin chemiluminescence measured after electrotransfection or EP (pulsing parameters: 6 pulses, $5 \mathrm{~ms}, 1 \mathrm{~Hz}$ ) (a) and after EP with the addition of antioxidants (pulsing parameters: $6 \times 500 \mathrm{Vcm}^{-1}, 5 \mathrm{~ms}, 1 \mathrm{~Hz}$ ) (b). Data represent the arithmetic mean \pm s.e.m. of 3-5 experiments normalized to untreated control group and cell viability. $P<0.05$ was considered statistically significant. * Statistically different from groups $0-300 \mathrm{Vcm}^{-1}$ and $500-600 \mathrm{Vcm}^{-1}$, including the same groups with plasmid DNA, **Statistically different from all groups, including the same group with plasmid DNA except $600 \mathrm{Vcm}^{-1}$, ${ }^{* *}$ Statistically different from all groups, including the same group with plasmid DNA except 500 and $700 \mathrm{Vcm}^{-1}$, $* * * *$ Statistically different from groups $0-300 \mathrm{Vcm}^{-1}$, including the same group with plasmid DNA, \#Statistically different from groups $0 \mathrm{Vcm}^{-1}$ with plasmid DNA, \#\#Statistically different from groups $0-100 \mathrm{Vcm}^{-1}$ with plasmid DNA, \#\#\#Statistically different from groups $0-600 \mathrm{Vcm}^{-1}$ with plasmid DNA.

membranes were already severely affected by EP and cell survival was also significantly reduced. These results indicated that ROS generated by EP interacted with DNA, which resulted in their neutralization by plasmid DNA (pEGFP-N1). ${ }^{40}$

Based on these results and results on optimized EP of C2C12 cells, 6 pulses with $500 \mathrm{Vcm}^{-1}$ were selected for further experiments, whereby $40 \%$ of permeabilized cells remained viable. 


\section{Antioxidants scavenge the ROS generated by EP}

Exposure of $\mathrm{C} 2 \mathrm{C} 12$ myoblasts to $\mathrm{EP}$ of $500 \mathrm{Vcm}^{-1}$ induced a significant increase in ROS generation on the cell membrane, up to 25-fold compared with untreated cells (Figures $2 \mathrm{a}$ and b). The addition of antioxidants before or after EP (10s) of cells significantly decreased the amount of ROS detected. The change of pulsing buffer conductivity due to the addition of scavengers did not affect the shape of the electric pulses delivered on the sample. The ROS scavenging effect of either vitamin $\mathrm{C}(4 \mathrm{mM})$ or tempol $(6 \mathrm{~mm})$ was equally effective; the values detected were in the range of untreated control cells, as well as in the range of cells exposed to antioxidants only (Figure 2b).

\section{EP induces small short-term nuclear DNA damage in cells but not on naked plasmid DNA}

The effect of EP on plasmid DNA integrity and genomic DNA was tested. Plasmid DNA, pEGFP-N1 was exposed to different electric pulse amplitudes $\left(400-600 \mathrm{Vcm}^{-1}, 6\right.$ pulses, $\left.5 \mathrm{~ms}, 1 \mathrm{~Hz}\right)$, and their possible effect on plasmid DNA fragmentation (change in mobility) was determined by agarose gel electrophoresis. The integrity of the plasmid DNA was intact at all the electric pulse amplitudes tested, from 400 to $600 \mathrm{Vcm}^{-1}$ (Figure 4). As a positive control, bleomycin ${ }^{41}$ was used, which caused significant plasmid fragmentation at 10 and $100 \mu \mathrm{M}$ (Figure 3a).

The damage of EP-induced ROS to genomic DNA in cells was quantified by the formation of 8-oxoguanin performed immediately after EP. At this early post-EP time, no oxidative genomic DNA damage was detected, either after exposure of cells to EP only, or plasmid (pEGFP-N1 plasmid) or a combination of the two (plasmid and EP) (Figure $3 \mathrm{~b}$ ).

The level of DNA damage after EP at longer intervals after EP was also evaluated by modified Comet assay, measuring DNA-strand breaks and oxidized purines. The exposure of cells to electric pulses $\left(6 \times 500 \mathrm{Vcm}^{-1}, 5 \mathrm{~ms}, 1 \mathrm{~Hz}\right)$ resulted in a small but significant increase of both DNA-strand breaks and formamidopyrimidine-DNA glycosylase (Fpg) sensitive sites at 15 and $30 \mathrm{~min}$ of recovery after $\mathrm{EP}$, which gradually decreased at $60 \mathrm{~min}$ post-EP, demonstrating the presence of efficient DNA repair mechanisms in C2C12 cells (Figure 4). Similar behavior was also demonstrated by DNA damage induced by tert-butyl hydroperoxide treatment (Figure 4).

All these experiments demonstrated that EP does not induce damage to DNA directly but indirectly in the presence of cells, as demonstrated by transient damage to genomic (nuclear) DNA. This DNA damage is negligible and present only for a short period after EP.

\section{Cytotoxicity of antioxidants alone or combined with DNA and EP on cell survival}

The effect of antioxidants alone or in combination with EP and plasmid DNA on cell survival was determined. The exposure of cells to vitamin $\mathrm{C}$ or tempol had some cytotoxic effect, but cell survival remained higher than $70 \%$ at the highest doses of antioxidants tested (Figure 5a). When antioxidants were added to the cells prior to or after EP, cell survival was slightly decreased but not more than $50 \%$ in comparison with EP alone (Figure 5a). When antioxidants were added to the cells exposed to plasmid DNA and EP, cell survival was decreased more with vitamin $\mathrm{C}$ than with tempol (Figures $5 \mathrm{a}$ and b). Tempol decreased cell survival to $\sim 40 \%$, while vitamin C to $4 \%$ at the highest dose tested $(25 \mathrm{~mm})$. Although not significant, the effects on cell survival were less pronounced with both tempol and vitamin C when antioxidants were added after EP (Figure 5b). Based on these results, we decided to use concentrations up to $6 \mathrm{~mm}$ for vitamin $\mathrm{C}$
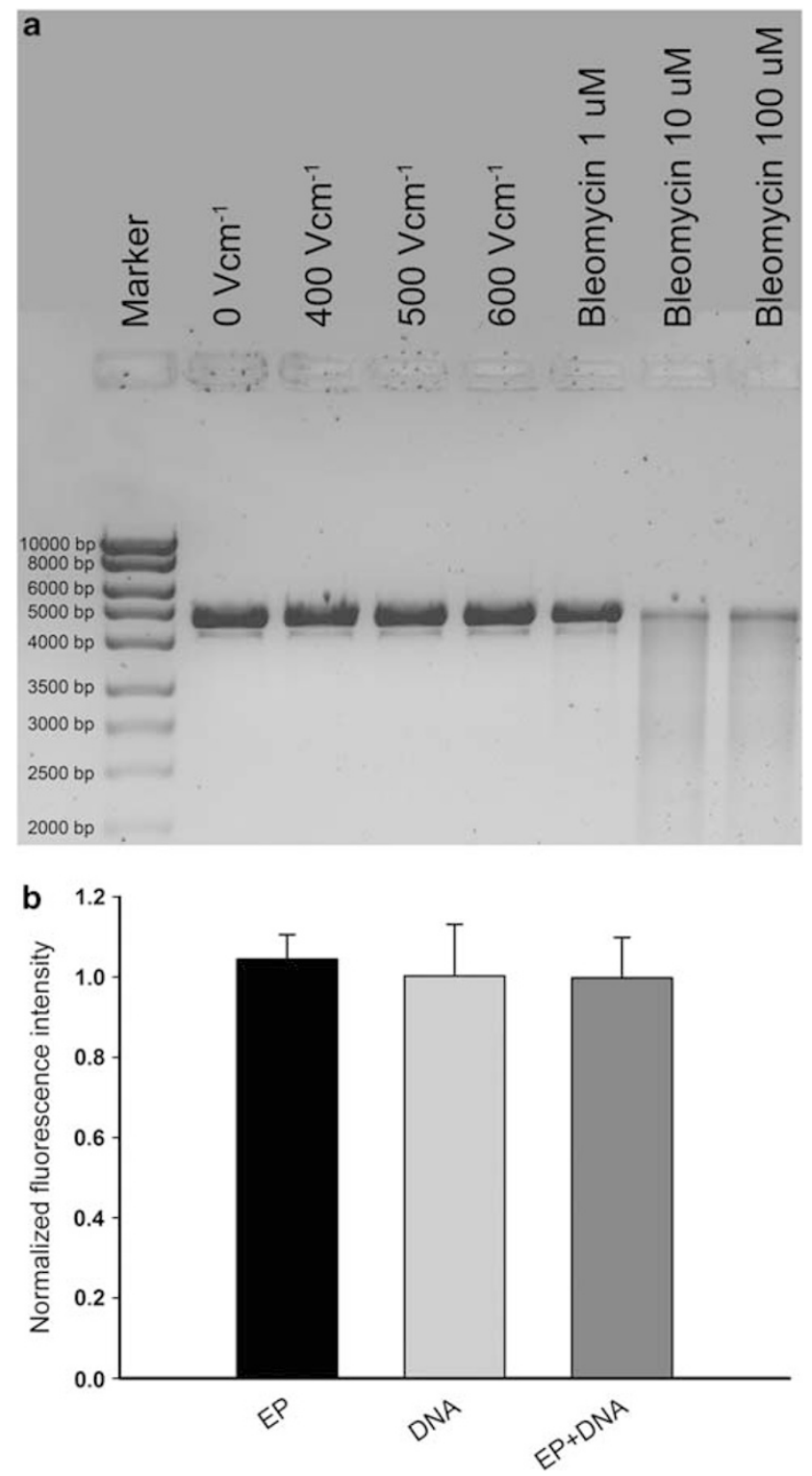

Figure 3 The integrity of plasmid DNA (pEGFP-N1) and genomic DNA damage after EP. Representative image of agarose gel electrophoresis of plasmid DNA ( $p$ EGFP-N1) after EP or the addition of bleomycin (a) and normalized fluorescence intensity of FITC conjugate bound to 8-oxoguanine after EP indicative of oxidative DNA damage (b). Pulsing parameters: $6 \times 400-600 \mathrm{Vcm}^{-1}, 5 \mathrm{~ms}, 1 \mathrm{~Hz}$ for (a) and $6 \times 500 \mathrm{Vcm}^{-1}, 5 \mathrm{~ms}, 1 \mathrm{~Hz}$ for (b). Groups: $0 \mathrm{~V}$ —plasmid DNA (pEGFP-N1), $400 \mathrm{~V}$ —plasmid DNA (pEGFPN1)+EP $400 \mathrm{Vcm}^{-1}, 500 \mathrm{~V}$-plasmid DNA (pEGFP-N1)+EP $500 \mathrm{Vcm}^{-1}$, $600 \mathrm{~V}$-plasmid DNA (pEGFP-N1)+EP $600 \mathrm{Vcm}^{-1}$, bleomycin 1, 10, $100 \mu \mathrm{M}$-plasmid DNA (pEGFP-N1)+bleomycin. Data in (b) represent the arithmetic mean \pm s.e.m. of three experiments normalized to the untreated control group: EP—electropermeabilization, DNA—pEGFP-N1 plasmid.

and up to $10 \mathrm{~mm}$ for tempol, which did not decrease cell survival below $\sim 40 \%$ in further experiments.

\section{Antioxidants increase electrotransfection efficiency in vitro}

The effect of antioxidants on the electrotransfection of $\mathrm{C} 2 \mathrm{C} 12$ cells was measured by flow cytometry and fluorescence microscopy. Flow cytometry demonstrated a statistically significant increase in the percentage of fluorescence cells when tempol was added before EP. 

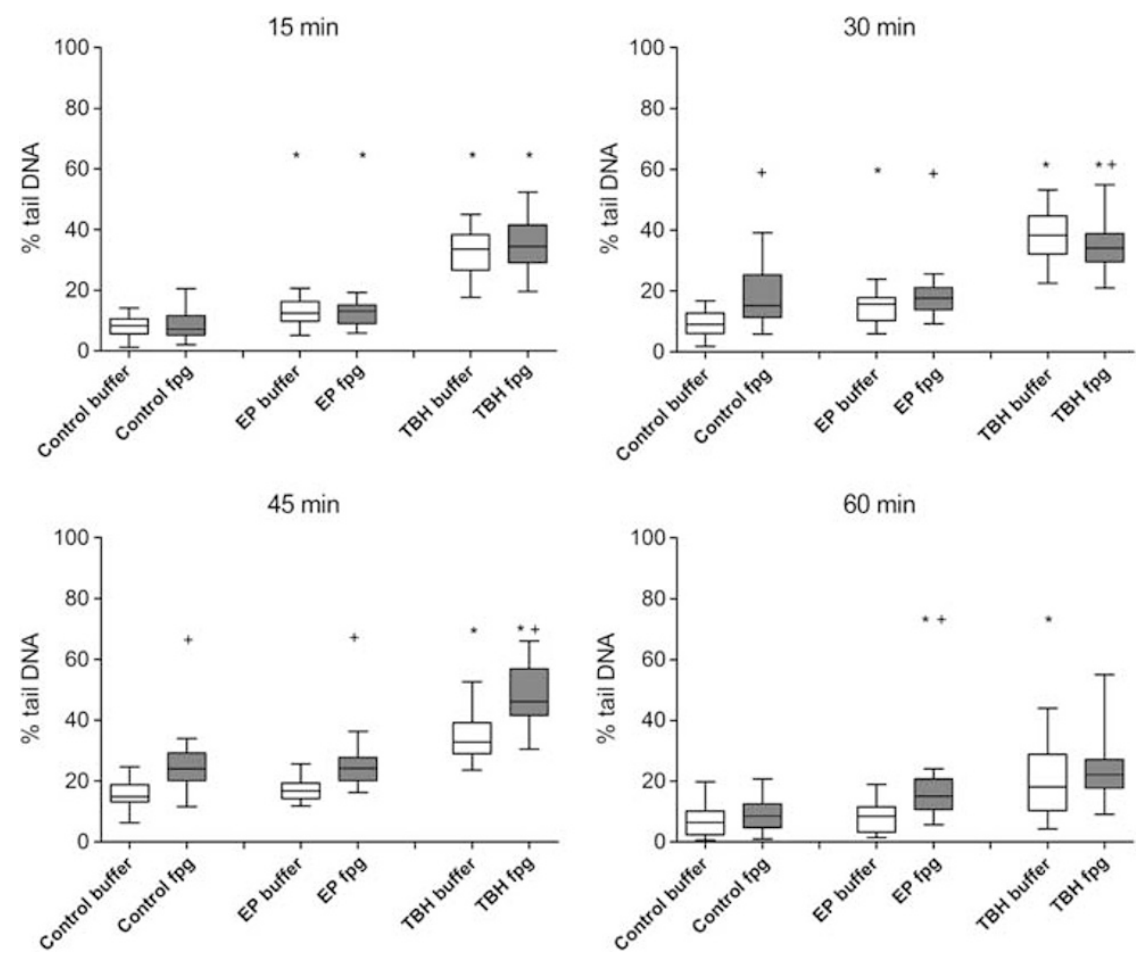

Figure 4 Genomic DNA damage after EP. Genomic DNA damage was determined by modified Comet assay with repair enzyme Fpg after the exposure of cells to EP or tert-butyl hydroperoxide. The results are presented as a percentage of tail DNA. Data are presented as quantile box plots. The edges of the box represent the 25 and 75th percentiles (95\% confidence intervals), the mean is a solid line through the box. The white box plots represent exposure to enzyme buffer (DNA-strand breaks), while dotted box plots represent exposure to Fpg enzyme (oxidized purines). Pulsing parameters: $6 \times 500 \mathrm{Vcm}{ }^{-1}, 5 \mathrm{~ms}$, $1 \mathrm{~Hz}$. Groups: 0 buffer-negative control group without enzyme treatment; *statistically different from the control group with the same treatment, ${ }^{+}$statistically significantly different between buffer exposed groups and Fpg enzyme exposed groups.

Transfection was increased by up to 1.6 -fold at $8 \mathrm{~mm}$ tempol (Figure 6a). At this setting, the median fluorescence intensity of transfected cells was also statistically increased by up to 1.8 -fold (Figure 6b). If tempol was added after EP of the cells (10s), no significant increase in transfection efficiency was detected (Figure 6a). Fluorescent microscopy confirmed the data from flow cytometry; an increased number of transfected cells was detected at $8 \mathrm{~mm}$ tempol, only when it was added to cells before EP (Figure 6c). Vitamin C had no effect on the transfection efficiency of $\mathrm{C} 2 \mathrm{C} 12$ cells; a decrease in transfection efficiency was even detected (Figure 6a).

\section{Tempol increases transfection efficiency in vivo in muscle}

In vivo transfection efficiency was determined in the $M$. tibialis cranialis in mice. Plasmid DNA (pEGFP-N1) mixed with tempol was injected into the $M$. tibialis cranialis and the muscle leg was electropulsated immediately thereafter. Analysis of fluorescent images of electrotransfected mice muscles (Figure $7 \mathrm{~b}$ ) demonstrated a 1.4 times increase in the transfected area at $12 \mathrm{~mm}$ concentration of added tempol in comparison with the control group on the 21st day after EP, which was a statistically significant increase (Figure 7a). The mean fluorescence intensity of the transfected area was not affected (Figure 7a).

\section{DISCUSSION}

The results of this study indicate that during EP of C2C12 cells, ROS are generated on the surface of the cells, which do not induce longterm genomic DNA damage. Plasmid DNA, which is present outside the cells during EP, neutralizes the ROS generated and, therefore, becomes inactivated. ROS generation is proportional to the amplitude of the electric pulses and can be scavenged by antioxidants, such as vitamin $\mathrm{C}$ or tempol. When antioxidants are used during gene electrotransfer, the transfection efficiency of $\mathrm{C} 2 \mathrm{C} 12$ myoblasts is increased, specifically, 1.6-fold by tempol. The in vivo, transfection efficiency of M. tibialis cranialis in mice is also increased by tempol, 1.4 -fold.

The generation of ROS after EP of Chinese hamster ovary cells has already been reported. ${ }^{38,39,42,43}$ Gabriel and Teissie ${ }^{42}$ demonstrated on Chinese hamster ovary cells that ROS are generated on the external layer of the cell membrane in the cap, which is electropermeabilized. The ROS generated were induced by exposure of the cells to 5 electric pulses of $500 \mathrm{Vcm}^{-1}$, a duration of $1 \mathrm{~ms}$, frequency $1 \mathrm{~Hz}$ and were detected by (Pam)-Afluorescein with fluorescence video microscopy on the level of a single cell. This phenomenon, the generation of ROS after EP of cells, was also detected with lucigenin and was dependent on the parameters of the EP, such as the amplitude of electric pulses, pulse duration and pulse number. ${ }^{39}$ Our study using lucigenin for the detection of ROS confirms previously published results, but on different cell line (C2C12 myoblasts), with pulse parameters used for gene electrotransfer $\left(6 \times 500 \mathrm{Vcm}^{-1}, 5 \mathrm{~ms}, 1 \mathrm{~Hz}\right) .{ }^{28}$ In this specific model of muscle cells, we demonstrated that more ROS are generated with increasing amplitude of electric pulses used. The complementarities of the results between the two different detection methods (Pam)-Afluorescein, which detects the ROS on the membrane, and lucigenin, which detects the ROS in the suspension close to the cell surface, indicate that the ROS are also generated in or on the cell membrane during the EP process in $\mathrm{C} 2 \mathrm{C} 12$ cells. Moreover, several studies have reported the induction of genes for radical scavenging molecules after EP. ${ }^{35-37}$ 

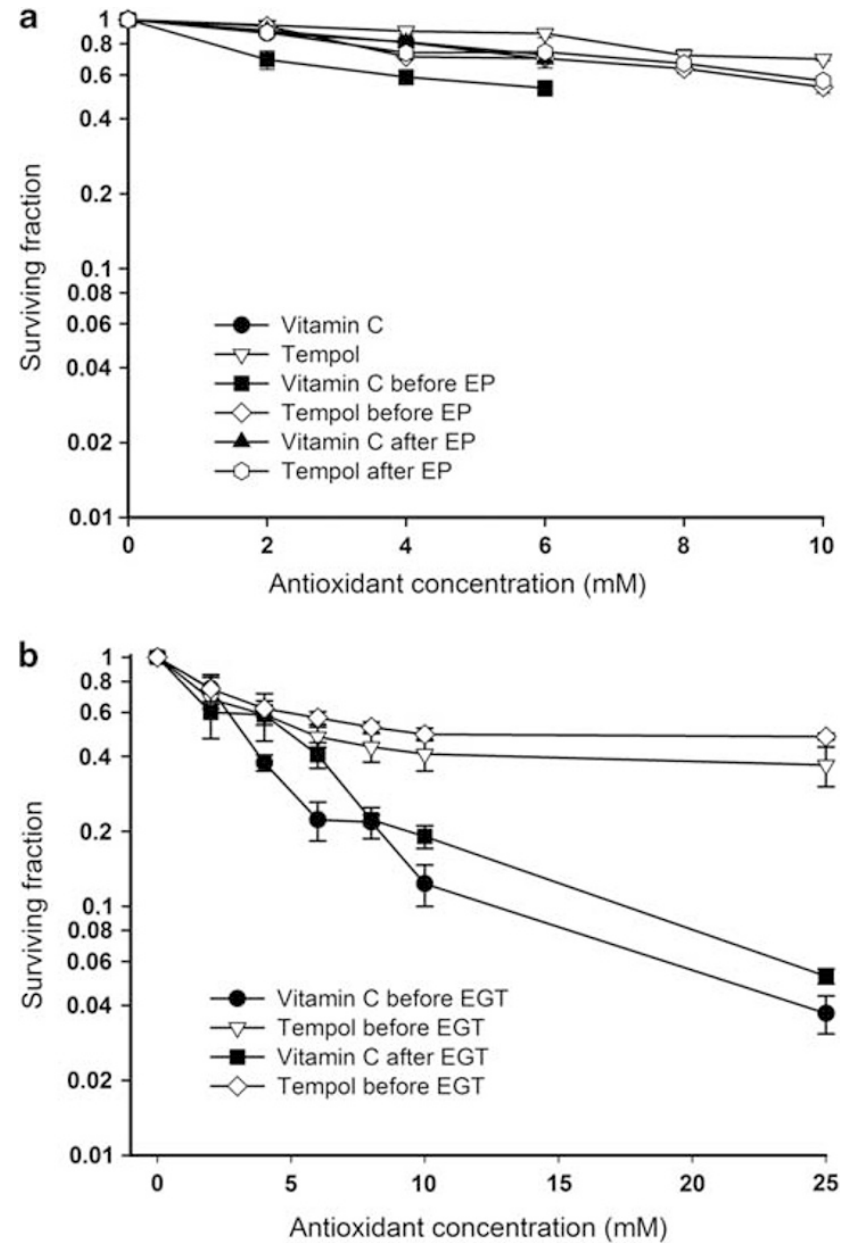

Figure 5 Cytotoxic effects of antioxidants (vitamin $\mathrm{C}$ and tempol) on $\mathrm{C} 2 \mathrm{C} 12$ cells. Cell survival was determined after exposure of cells to different concentrations of antioxidants (a) and combined with EP and pEGFP-N1 (EGT-EP+pEGPF-N1) (b). Pulsing parameters: $6 \times 500 \mathrm{Vcm}^{-1}, 5 \mathrm{~ms}, 1 \mathrm{~Hz}$. Data represent arithmetic mean \pm s.e.m. of three experiments normalized to untreated control group or to the group exposed only to EP or EGT, where EP or EGT is present.

However, nobody has been able to present solid evidence of ROS generation inside the cytoplasm after EP of cells. There is some indication by Shil, ${ }^{44}$ who used 2,7',-dichlorodihydrofluorescein diacetate for ROS detection and, under different experimental conditions than ours, showed an increase in intracellular ROS generation with increasing amplitude of electric pulses. Similar results were obtained after ionizing radiation but at an $\sim 50 \%$ higher extent.

In our study, the presence of intracellular ROS was implicated indirectly by measurement of genomic DNA damage. The indication that DNA damage is generated by ROS and not by EP directly is supported by the fact that damage to genomic DNA could not be detected immediately after exposure of cells to EP, as demonstrated by the 8-oxoG assay. Genomic DNA damage after a longer post-EP interval was detected using the Comet assay. The genomic DNA damage was minimal compared with the damage caused by tert-butyl hydroperoxide, which was used as a positive control, and transient (detected only at 15 and 30 min intervals), showing effective DNA repair within $60 \mathrm{~min}$ after EP. In addition, we demonstrated that exposure of plasmid DNA to different electric parameters did not result in plasmid DNA fragmentation. Similar results were obtained by
Goldberg, who demonstrated that exposure of isolated genomic DNA to EP of electric parameters used for gene electrotransfer does not induce direct DNA damage/fragmentation. ${ }^{45}$

Plasmid DNA, which is present during EP, neutralized the generated ROS. The oxidation of DNA in the presence of ROS that are generated during the normal metabolic process in cells is a well-known phenomenon that occurs naturally in every cell. ${ }^{40}$ If the cell is exposed to oxidative stress, the oxidation of DNA is increased. If the plasmid DNA used for electrotransfection reacts with ROS generated during EP, the detection of ROS by lucigenin should, therefore, be reduced. We demonstrated that the ROS derived chemiluminescence of lucigenin was reduced when plasmid DNA was present around the cells during EP. The addition of $10 \mu \mathrm{g}$ of plasmid DNA to the cells completely prevented the detection of ROS by lucigenin after EP. We observed the same effect on detection of ROS by the addition of antioxidants such as vitamin $\mathrm{C}$ and tempol to cells exposed to EP. In view of these data, we can assume that the generated ROS interacted with plasmid DNA present during the EP of the cells.

In the next step, we tried to improve transfection efficiency by the use of antioxidants. Electrotransfection is a multistep process ${ }^{1}$ that requires the formation of DNA-cell membrane complexes for effective transfection. ${ }^{46}$ The interaction between the ROS generated during the application of electric pulses and plasmid DNA complexed with the cell membrane could, therefore, affect the transfection efficiency. The addition of ROS scavengers, antioxidants, to cells prior to EP might neutralize the generated ROS as soon as they are formed and the plasmid DNA in the DNA-cell membrane complexes would not be affected. The electrotransfection efficiency could consequently be improved. Indeed, our in vitro data indicate that the transfection of pEGFP-N1 in the C2C12 cell line was increased by $60 \%$ when tempol was added before EP, which indicates that, by modulating the generated ROS, we can affect the transfection efficiency. The ROS generated due to EP on the cell surface must affect the plasmid DNA very rapidly, since there was no increase in transfection efficiency if tempol was added after the EP. A positive effect of antioxidants, such as ascorbic acid, on expression levels after electrotransfection has been reported in plant cells, ${ }^{47}$ but to our best knowledge, there has been no report of increased electrotransfection efficiency in animal cells in vitro or in vivo following (due to) the addition of antioxidants.

In vivo, in mouse muscle, tempol increased transfection efficiency by $40 \%$. The transfection efficiency was increased when tempol was mixed with plasmid DNA and injected together into the M. tibialis cranialis, which was immediately thereafter exposed to EP. The increase was evident only at a $12-\mathrm{mm}$ tempol concentration. The transfected area was increased but not the quantity of the GFP in the cells, indicating that more muscle fibers were transfected when the antioxidant was present, while the amount of plasmid DNA introduced in a single fiber was not changed compared with control. Altogether, that means that a higher expression of GFP (number of expressed proteins) was induced. A lower dose was probably not high enough to scavenge enough generated ROS to affect transfection efficiency. At a higher dose, the positive effect of tempol on scavenging EP generated ROS was probably counteracted by additional ROS formation caused by tempol-initiated lipid peroxidation, ${ }^{48}$ resulting in a similar level of transfection efficiency as in control muscles exposed to EP alone. We observed the same effect in vitro.

Tempol is widely used as a promoter of the metabolism of many ROS. It has been used in many different studies in vitro and in vivo. In vitro it has been shown that it can preserve mitochondria against oxidative damage. In vivo in many preclinical models, it has been demonstrated that tempol improved survival in several shock models 
a

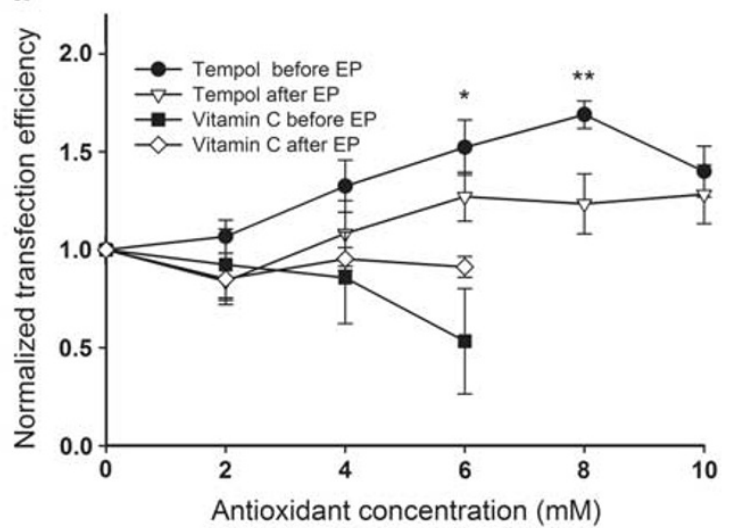

b

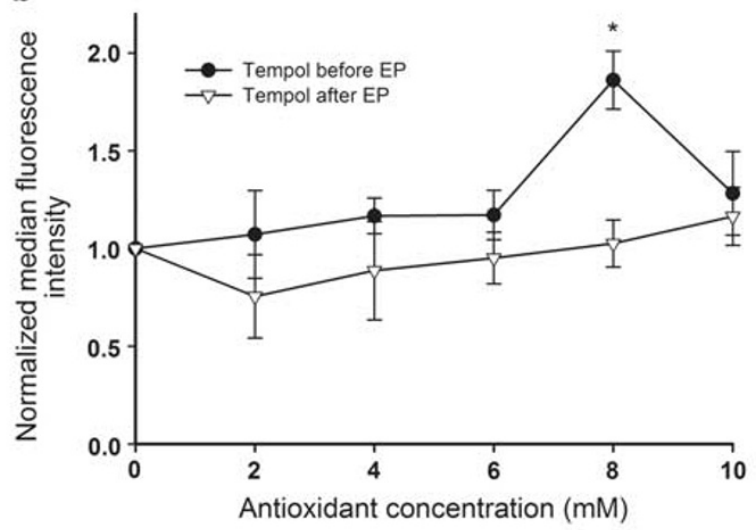

C

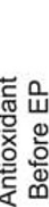

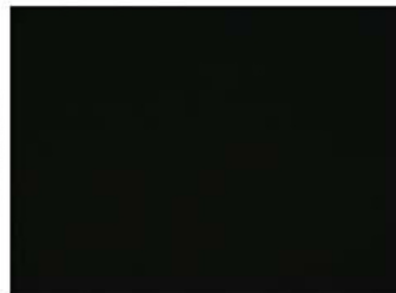

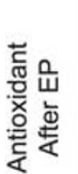

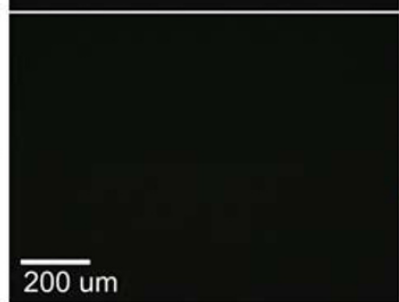

EGT

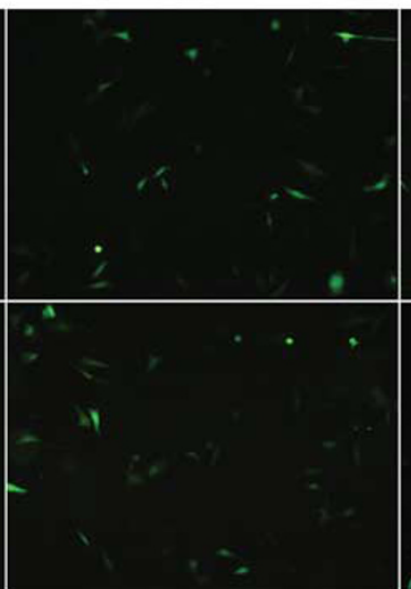

$E G T+$ tempol $8 \mathrm{mM}$

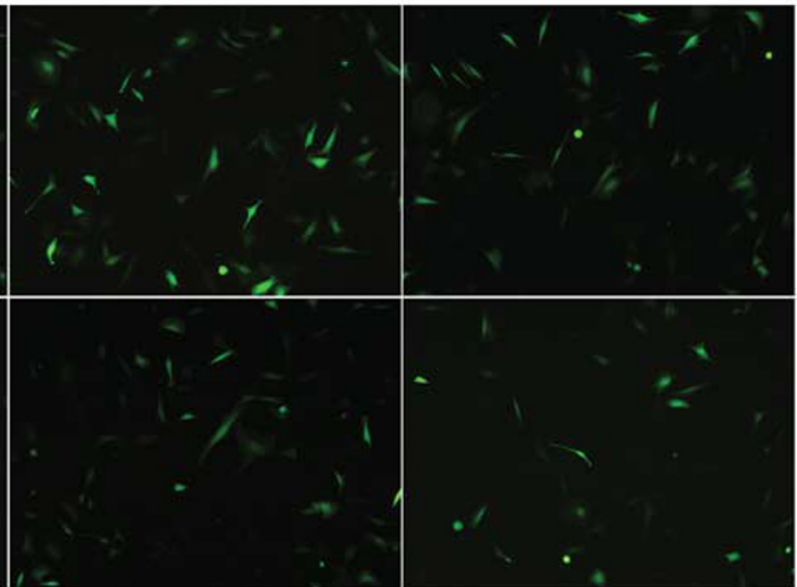

Figure 6 Increased in vitro transfection efficiency of pEGFP-N1 plasmid into C2C12 cells after the addition of tempol before EP. Fraction of enhanced GFP expressing cells (a) and normalized median fluorescence intensity of enhanced GFP expressing cells (b). Images of cells electrotransfected with pEGFP-N1 plasmid acquired with fluorescent microscope (c) (excitation: $460-490 \mathrm{~nm}$, emission: $505 \mathrm{~nm}$ ). Pulsing parameters: $6 \times 500 \mathrm{Vcm}^{-1}, 5 \mathrm{~ms}, 1 \mathrm{~Hz}$. Data in (a) and (b) represent arithmetic mean \pm s.e.m. of three to five experiments normalized to control group in which no antioxidants were added. $P<0.05$ was considered statistically significant. *Statistically different from control group and the same concentration of tempol after EP, **Statistically different from control group, all tempol before EP groups except tempol $6 \mathrm{~mm}$ and from tempol $8 \mathrm{~mm}$ after EP. Groups in (c): plasmid+EP-EGT, pEGFP-N1 plasmid+EP+tempol $8 \mathrm{~mm}-E G T+$ tempol $8 \mathrm{~mm}$, plasmid+EP+tempol $10 \mathrm{~mm}-E G T+$ tempol $10 \mathrm{~mm}$, addition of antioxidant after EP-antioxidant after EP, addition of antioxidant before EP-antioxidant before EP. Where no antioxidant was added, the treatment of cells was the same for both parallel groups.

in mice, protecting many organs, including the heart and brain, from ischemia/reperfusion damage, reducing the consequences of oxidative stress and inflammation after radiation, reducing blood pressure and so on. However, in humans, the compound has only been used as a topical agent to prevent radiation-induced alopecia. ${ }^{48,49}$ To the best of our knowledge, tempol has not been used as an agent to increase transfection efficiency. The doses of tempol used in our study were lower than the reported toxic doses for mice and rats ${ }^{49}$ and no side effects were recorded.

The antioxidant tempol is, therefore, a promising compound, which can also be used to improve electrotransfection efficiency in tissues. Muscle is easy to transfect; however, there are other tissues, such as skin and, especially, tumors, in which higher transfection efficiency would result in a better clinical effect. Several approaches are being investigated, especially in tumors, to increase transfection efficiency, such as pulse parameter selection, modulation of extracellular matrix, the time interval between DNA injection and application of EP, plasmid preparation and so on. ${ }^{15,16,18,27-29,50}$ In the present study, we demonstrated the importance of ROS generation after EP on transfection efficiency and showed that the use of tempol can significantly improve electrotransfection in a model tissue-muscle.

\section{MATERIALS AND METHODS}

\section{Cell line}

Mouse myoblast cell line C2C12 (ATCC, Rockville, VA, USA) was cultured in Eagle's Minimum Essential Medium (Gibco, Grand Island, NY, USA) supplemented with $10 \%$ fetal bovine serum, $10 \mathrm{~mm}$ glutamin (Gibco BRL, Paisely, UK), $350 \mu \mathrm{gl}^{-1}$, gentamycin (Krka, Novo mesto, Slovenia) and $1 \mathrm{mll}^{-1}$ crystacillin (Pliva d.d., Zagreb, Croatia) in a $5 \% \mathrm{CO}_{2}$ humidified incubator at $37^{\circ} \mathrm{C}$.

\section{Reagents}

Cell permeable antioxidants, vitamin $\mathrm{C}$-ascorbic acid and tempol—4-hydroxy-2,2,6,6-tetramethylpiperidine-1-oxyl, were purchased from Sigma-Aldrich (St Louis, MO, USA). The concentrations used in the experiments were prepared by dissolving the antioxidants in phosphate-buffered saline (PBS) for in vitro and in $\mathrm{dH}_{2} \mathrm{O}$ for in vivo experiments. The concentrations of vitamin $\mathrm{C}$ and tempol used in the in vitro experiments ranged from 2 to $25 \mathrm{~mm}$. In the 


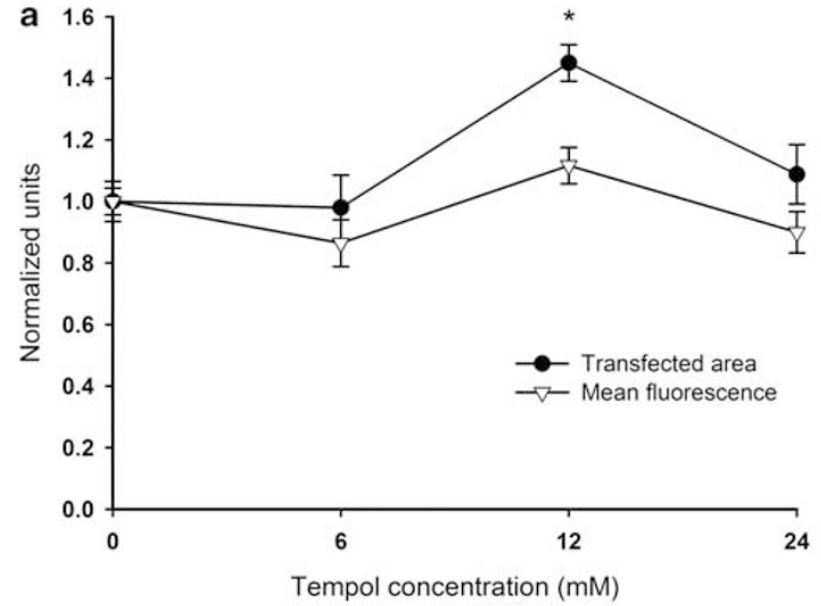

b
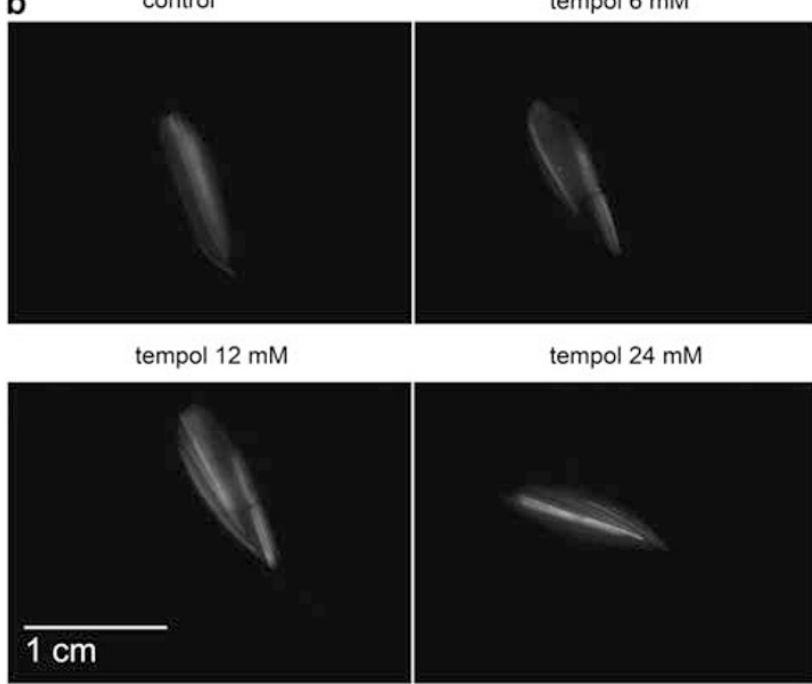

Figure $\mathbf{7}$ Increased transfected area (area) and mean fluorescence of transfected area (mean fluorescence) of electrotransfected $M$. tibialis cranialis after the addition of tempol. Transfected area and mean fluorescence intensity were determined by analysis of the acquired images of M. tibialis cranialis (a) and imaged with a fluorescent stereomicroscope (excitation: 470/40 nm, emission: 525/50 nm) (b). Pulsing parameters: $1 \times 600 \mathrm{Vcm}^{-1}, 100 \mu \mathrm{s}, 1 \mathrm{~Hz}+4 \times 80 \mathrm{Vcm}^{-1}, 100 \mathrm{~ms}, 1 \mathrm{~Hz}$. Groups in (b): plasmid+EP-control, plasmid+EP+tempol $6 \mathrm{~mm}$-tempol $6 \mathrm{~mm}$, plasmid+EP+tempol $12 \mathrm{~mm}$-tempol $12 \mathrm{~mm}$, plasmid+EP+tempol $24 \mathrm{~mm}-$ tempol $24 \mathrm{~mm}$. Data in (a) represent the arithmetic mean \pm s.e.m. of 13-35 mice legs normalized to the control group in which no antioxidants were added. $P<0.05$ was considered statistically significant. *Statistically different from all other groups.

in vivo experiments, the concentration of tempol was 6, 12 or $24 \mathrm{~mm}$. Propidium iodide (P4170, Sigma-Aldrich) was resuspended in EP buffer to a final concentration of $100 \mu \mathrm{m}$. Lucigenin-9,9'-Bis( $N$-methylacridinium nitrate) (Sigma-Aldrich) was resuspended in PBS to a final concentration of $5 \mathrm{~mm}$.

Agarose and ethidium bromide $\left(10 \mathrm{mg} \mathrm{m}^{-1}\right)$ for electrophoresis were purchased from Sigma-Aldrich. The EcoR1 enzyme, corresponding buffer (React3) and DNA ladder mix were bought from Fermentas Inc. (Glen Burnie, MD, USA).

Plasmid pEGFP-N1 (Clontech Laboratories Inc., Mountain View, CA, USA), encoding enhanced GFP was prepared from Escherichia coli cultures using the Qiagen Endo-Free Plasmid Mega kit (Qiagen, Hilden, Germany) according to the manufacturer's instructions and diluted to a working concentration of $1 \mu \mathrm{gl}^{-1}$. In all in vitro experiments, $10 \mu \mathrm{g}$ of DNA was used.
Normal melting point agarose, low melting point agarose and ethidium bromide solution for the Comet assay were from Gibco (Gibco BRL). Fpg was a gift from Dr Andrew R Collins (Department of Nutrition, University of Oslo, Oslo, Norway) and concentrations of the enzyme were prepared according to his protocol. All other chemical reagents were of the purest grade available and all solutions were made using Mill-Q water.

\section{In vitro $\mathrm{EP} / \mathrm{electrotransfection} \mathrm{protocol}$}

The $\mathrm{C} 2 \mathrm{C} 12$ cells grown as a monolayer were collected and a cell suspension with a concentration of $3.3 \times 10^{7}$ cells ml ${ }^{-1}$ was prepared in EP buffer (EP buffer: $125 \mathrm{~mm}$ sucrose, $10 \mathrm{~mm} \mathrm{~K}_{2} \mathrm{HPO}_{4}, 2.5 \mathrm{mM} \mathrm{KH}_{2} \mathrm{PO}_{4}, 2 \mathrm{mM} \mathrm{MgCl}_{2} \times 6$ $\mathrm{H}_{2} \mathrm{O}$ ). Antioxidants, $\mathrm{dH}_{2} \mathrm{O}$ and/or plasmid DNA or propidium iodide were added to the prepared cell suspension and $50 \mu \mathrm{l}$ of mixture was then placed between two flat parallel stainless steel electrodes with a 2-mm gap, connected to a GT-1 electropulsator (University of Ljubljana, Faculty of Electrical Engineering, Ljubljana, Slovenia) or Jouan PS 10 electropulsator (St Herblain, France) and subjected to various numbers of square wave pulses $(4,6,8)$ with various amplitude per distance ratios $\left(0-900 \mathrm{Vcm}^{-1}\right), 5 \mathrm{~ms}$ duration and $1 \mathrm{~Hz}$ repetition frequency. After pulsing, the electrodes were washed with $100 \mu \mathrm{l}$ of $1 \times$ PBS or dissolved antioxidant (antioxidant concentrations were calculated to working volume of $150 \mu \mathrm{l})$. Subsequently, the cells in a $150-\mu \mathrm{l}$ volume were incubated for $5 \mathrm{~min}$ at room temperature, then the growth medium was added. Thereafter, cell viability, permeabilization, survival and transfection were determined as described below.

\section{Cell permeabilization and viability}

Cells were electropermeabilized $\left(0-900 \mathrm{Vcm}^{-1}, 4-8\right.$ pulses, $\left.5 \mathrm{~ms}, 1 \mathrm{~Hz}\right)$ in the presence of $100 \mu \mathrm{m}$ propidium iodide (Sigma-Aldrich) dissolved in EP buffer. Membrane re-sealing occurred $5 \mathrm{~min}$ after pulse application, keeping internalized propidium iodide trapped. Cells were then analyzed by FACSCalibur flow cytometer (BD Biosciences, San Jose, CA, USA) to determine the percentage of permeabilized cells (that is fluorescent cells). Crystal violet (Merck, Darmstadt, Germany) staining was used to determine the viability of the cells $24 \mathrm{~h}$ after EP.

\section{Cell survival}

Cell survival was determined by clonogenic assay. After a particular treatment, the cells (300-800) were plated on $6 \mathrm{~cm}$ petrie dishes with $4 \mathrm{ml}$ growth medium and placed in a $5 \% \mathrm{CO}_{2}$ humidified incubator at $37^{\circ} \mathrm{C}$. After 10-12 days, the colonies were stained with crystal violet and then counted. Colonies of fewer than 50 cells were ignored. Plating efficiency and the surviving fraction were calculated. The experiments were performed in triplicate and repeated three times.

\section{Cell transfection}

The expression of GFP in the cells was monitored with an FACSCanto II flow cytometer (BD Biosciences) and fluorescent microscope Olympus IX70 (excitation: $460-490 \mathrm{~nm}$, emission: $505 \mathrm{~nm}$, Olympus, Hamburg, Germany). The images were taken with a digital camera (DP 50, Olympus). After EP, the cells were plated on $6 \mathrm{~cm}$ petrie dishes with $4 \mathrm{ml}$ growth medium and placed in a $5 \%$ $\mathrm{CO}_{2}$ humidified incubator at $37^{\circ} \mathrm{C}$. After 2 days, the cells were collected and the number of GFP expressing cells was quantified by flow cytometer. A histogram of cell number against fluorescence was recorded. The percentage of GFP expressing cells represented the transfection efficiency. Transfection efficiencies of samples treated with antioxidants were then normalized to an untreated control sample (cells electropermeabilized in the presence of GFP) to obtain normalized transfection efficiency.

\section{In vitro ROS detection after EP}

A concentration of $1,25 \times 10^{8}$ cells ml ${ }^{-1}$ was prepared in EP buffer. A total of $40 \mu \mathrm{l}$ of the suspension was mixed with either $10 \mu \mathrm{l}$ of plasmid DNA, antioxidants or $\mathrm{dH}_{2} \mathrm{O}$ and $50 \mu \mathrm{l}$ of mixture was electropermeabilized as described above. Immediately after pulsing, the electrodes were washed with $290 \mu \mathrm{l}$ of PBS buffer into 96-well plates (Corning Inc., New York, NY, USA) and $10 \mu \mathrm{l}$ of $5 \mathrm{~mm}$ lucigenin was added. The cells were then immediately (10 s) put into a multimode microplate reader (Infinite 200, Tecan, Männendorf, Switzerland) and chemiluminescence was measured every $3 \mathrm{~s}$ for $300 \mathrm{~s}$. The acquired 
data were plotted and smoothed to create a curve. The local maximum of the curve represented the increased chemiluminescence signal due to ROS generation.

To determine the effect of antioxidants on in vitro ROS production, the antioxidants were added in two different ways. First, the antioxidants were added to the cell suspension after EP $(290 \mu \mathrm{l}$ of antioxidant dissolved in $1 \times$ PBS buffer) instead of PBS buffer and second, $10 \mu \mathrm{l}$ of antioxidants were added to the cell suspension just before EP $(<5 \mathrm{~s})$. The concentrations were calculated to a working volume of $350 \mu \mathrm{l}$. The data were normalized to the control group, in which the cells were not subjected to EP and cell viability.

\section{Determination of plasmid DNA integrity}

In order to determine the effect of electric pulses on plasmid DNA integrity, $1 \mu \mathrm{l}$ of pEGFP-N1 plasmid was resuspended in $49 \mu \mathrm{l}$ of EP buffer. The mixture was then exposed to electric pulses $\left(6 \times 500 \mathrm{Vcm}^{-1}, 5 \mathrm{~ms}, 1 \mathrm{~Hz}\right)$ or to different concentrations of bleomycin $(1,10,100 \mu \mathrm{M})$ for positive control and then incubated for $4 \mathrm{~h}$ in a water bath at $37^{\circ} \mathrm{C}$, with shaking. After incubation, $7 \mu \mathrm{l}$ of the sample was mixed with $1 \mu \mathrm{l}$ of EcoR1 enzyme and $2 \mu \mathrm{l}$ of corresponding buffer (React3) and then incubated for $1 \mathrm{~h}$ in a water bath at $37^{\circ} \mathrm{C}$, with shaking. The restricted samples, containing $140 \mathrm{ng}$ of pDNA, were then transferred to $1 \%$ agarose gel stained with ethidium bromide and electrophoresis run for $2 \mathrm{~h}$ at $50 \mathrm{Vcm}^{-1}$. An image of the gel was taken with the GelDoc-it imaging system (UVP, Upland, CA, USA) under ultraviolet light.

\section{Determination of oxidative DNA damage of genomic (nuclear) DNA after EP}

In order to determine whether EP causes any oxidative DNA damage to cells, 8-oxoguanine, which is formed from guanine after interaction of genomic DNA with ROS, was quantified by OxyDNA test kit (8-oxoG assay; Merck KGaA, Darmstadt, Germany). The cells were subjected to 6 square wave electric pulses of $500 \mathrm{Vcm}^{-1}$ amplitude per distance ratio, $5 \mathrm{~ms}$ duration time and $1 \mathrm{~Hz}$ repetition frequency. Immediately $(<5 \mathrm{~s})$ after EP, the cells were fixed in $4 \%$ formaldehyde and then permeabilized with $0.1 \%$ Triton and washed several times with wash solution supplied with the kit. After washing, FITC conjugate, which binds to 8-oxoguanin, was added to the cell pellet and the cells were incubated for $60 \mathrm{~min}$ at room temperature. The cells were again washed with $1 \times$ PBS and the cells were then analyzed by FACSCanto II flow cytometer (BD Biosciences). Histograms of cell number against fluorescence were recorded. The mean fluorescence of the cell sample was then normalized to the untreated control group.

\section{Determination of nuclear DNA damage after EP}

Single cell gel electrophoresis, also called the Comet assay, is a very sensitive method for detecting DNA double-strand breaks and single-strand breaks, alkali labile sites such as apurinic/apyrimidinic sites, DNA-DNA and DNAprotein cross-links and single-strand breaks associated with incomplete excision repair. ${ }^{51}$ The genomic oxidative DNA damage induced by EP was measured with the modified Comet assay, as described by Collins et al..$^{52}$ with minor modifications, ${ }^{53}$ using lesion-specific DNA repair enzyme Fpg, which converts oxidized purines to apyrimidinic sites and strand breaks. ${ }^{54,55} \mathrm{C} 2 \mathrm{C} 12$ cells were electropermeabilized as described above and left in an incubator at $37^{\circ} \mathrm{C}$ in $5 \%$ $\mathrm{CO}_{2}$. For positive control of DNA damage, the cells were incubated for $15 \mathrm{~min}$ on ice with $100 \mu \mathrm{m} \mathrm{tBOOH}$ (tert-butyl hydroperoxide, Sigma-Aldrich). After $15,30,45$ and $60 \mathrm{~min}$ of cell recovery at $37^{\circ} \mathrm{C}, 30 \mu \mathrm{l}$ of cell suspension was mixed with $70 \mu \mathrm{l}$ of $1 \%$ low melting point agarose and added to fully frosted slides that had been covered with a layer of $1 \%$ normal melting point agarose. The slides were subsequently lysed $(2.5 \mathrm{M} \mathrm{NaOH}, 0.1 \mathrm{M}$ ethylenediaminetetraacetic, $0.01 \mathrm{M}$ Tris, $\mathrm{pH} 10$ and $1 \%$ Triton X-100) for $1 \mathrm{~h}$ at $4{ }^{\circ} \mathrm{C}$. After the lysis, the slides were washed three times for $5 \mathrm{~min}$ in endonuclease buffer solution ( $40 \mathrm{~mm}$ HEPES-KOH, $0.1 \mathrm{M} \mathrm{KCl}, 0.5 \mathrm{~mm}$ EDTA, $0.2 \mathrm{mg} \mathrm{m}^{-1}$ bovine serum albumin, $\mathrm{pH}$ 8.0). A total of $50 \mu \mathrm{l}$ aliquots of Fpg solution or enzyme buffer without Fpg were added to the gel, covered with a cover glass and incubated at $37^{\circ} \mathrm{C}$ for $30 \mathrm{~min}$ as described by the manufacturer. After the incubation, the slides were placed in the electrophoresis solution $(300 \mathrm{~mm} \mathrm{NaOH}, 1 \mathrm{~mm}$ EDTA, $\mathrm{pH}$ 13) for $20 \mathrm{~min}$ to allow DNA unwinding, and electrophoresed for $20 \mathrm{~min}$ at $25 \mathrm{~V}(300 \mathrm{~mA})$. Finally, the slides were neutralized with $0.4 \mathrm{M}$ Tris buffer $(\mathrm{pH}$ 7.5), stained with ethidium bromide $\left(5 \mu \mathrm{g} \mathrm{ml}^{-1}\right)$ and analyzed using a fluorescence microscope (Nikon Eclipse 800, Tokyo, Japan). Images of 50 randomly selected nuclei per experimental point were analyzed with image analysis software Comet Assay IV (Perceptive Instruments, Haverhill, UK). The results from two independent experiments performed each time in two parallels are expressed as a percentage of tail DNA and are shown as box plots.

\section{Experimental animals}

Female C57Bl/6 mice were used in the experiments (Institute of Pathology, Faculty of Medicine, University of Ljubljana, Slovenia). Experimental protocols were in accordance with the guidelines for animal experiments of European Union directives and a permit from the Ministry of Agriculture, Forestry and Food of the Republic of Slovenia. (Permit no.: 34401-11/2009/6). The age of the mice that were included in the experiments was between 12 and -16 weeks. Mice were kept under specific pathogen-free conditions at a constant room temperature $\left(21{ }^{\circ} \mathrm{C}\right)$ and a 12 -h light/dark cycle. Food and water were provided ad libitum. Animals were subjected to an adaptation period of 1 week before experiments. The experiments were performed three times. Experimental groups consisted of 6-18 animals.

\section{In vivo electrotransfection of $M$. tibialis cranialis}

Both mouse hind legs were shaved and then depilated with hair removal cream (Vitaskin, Krka d.d). To increase the randomization, each leg was assigned to different experimental group. Before EP, the mice were anesthetized with Isofluran (Torrex Chiesi Pharma GmbH, Vienna, Austria). Muscle electrotransfection was performed according to our previously described protocol. ${ }^{29}$ Briefly, $20 \mu \mathrm{g}$ of DNA in $30 \mu \mathrm{l}$ of $\mathrm{dH}_{2} \mathrm{O}$ for the control group or $20 \mu \mathrm{g}$ of DNA in $20 \mu \mathrm{l}$ of $\mathrm{dH}_{2} \mathrm{O}$ mixed with $10 \mu \mathrm{l}$ of dissolved antioxidants was injected into the muscle $<5 \mathrm{~s}$ before EP; EP was then performed with CLINIPORATOR (IGEA s.r.l., Carpi, Italy). Transfection efficiency in vivo was monitored with a fluorescent stereomicroscope (excitation: $470 / 40 \mathrm{~nm}$, emission: 525/50 nm, SteREOLumar V.12, Carl Zeiss, Jena, Germany), equipped with an AxioCam MRc5 digital camera (Carl Zeiss), on the 7th and 21st day after EP. The transfected area was separated from the non-transfected area by determining a threshold value for pixel intensity on every image. Pixels with greater intensity than the threshold value gave the transfected area. Values were normalized to the group in which no antioxidants were used. Transfection efficiency was determined as the normalized fluorescent area and the normalized mean fluorescence intensity of the fluorescent area on images of M. tibialis cranialis. ImageJ software (National Institute of Mental Health, Bethesda, MD, USA) was used for image analysis.

\section{Statistical analysis}

All data were tested for normality of distribution using the KolmogorovSmirnov test. Differences between experimental groups were statistically evaluated by one-way analysis of variance followed by the Holm-Sidak test for multiple comparisons. A $P$-value $<0.05$ was considered to be statistically significant. SigmaPlot Software (Systat Software, London, UK) was used for statistical analysis and graphical presentation. For the Comet assay, one-way analysis of variance (Kruskal-Wallis) was used to analyze differences between treatments within each experiment. Dunnett's test was used for comparison versus the control; $P<0.05$ was considered to be statistically significant.

\section{CONFLICT OF INTEREST}

The authors declare no conflict of interest.

\section{ACKNOWLEDGEMENTS}

We acknowledge financial support from the state budget through the Slovenian Research Agency (program no. P3-0003) and French-Slovenian Scientific Cooperation (PROTEUS and PICS).

1 Teissie J, Golzio M, Rols MP. Mechanisms of cell membrane electropermeabilization: a minireview of our present (lack of ?) knowledge. Biochim Biophys Acta 2005; 1724: 270-280. 
2 Miklavcic D, Towhidi L. Numerical study of the electroporation pulse shape effect on molecular uptake of biological cells. Radiol Oncol 2010; 44: 34-41.

3 Miklavcic D, Snoj M, Zupanic A, Kos B, Cemazar M, Kropivnik M et al. Towards treatment planning and treatment of deep-seated solid tumors by electrochemotherapy. Biomed Eng Online 2010; 9: 10

4 Sersa G, Miklavcic D, Cemazar M, Rudolf Z, Pucihar G, Snoj M. Electrochemotherapy in treatment of tumours. Eur J Surg Oncol 2008; 34: 232-240.

5 Moller MG, Salwa S, Soden DM, O'Sullivan GC. Electrochemotherapy as an adjunct or alternative to other treatments for unresectable or in-transit melanoma. Expert Rev Anticancer Ther 2009; 9: 1611-1630.

6 Marty M, Sersa G, Garbay JR, Gehl J, Collins CG, Snoj M et al. Electrochemotherapyan easy, highly effective and safe treatment of cutaneous and subcutaneous metastases: results of ESOPE (European Standard Operating Procedures of Electrochemotherapy) study. Eur J Cancer Supp/ 2006; 4: 3-13.

7 Neumann E, Schaefer-Ridder M, Wang Y, Hofschneider PH. Gene transfer into mouse lyoma cells by electroporation in high electric fields. EMBO J 1982; 1: 841-845.

8 Titomirov AV, Sukharev S, Kistanova E. In vivo electroporation and stable transformation of skin cells of newborn mice by plasmid DNA. Biochim Biophys Acta 1991; 1088: 131-134.

9 Cemazar M, Golzio M, Sersa G, Rols MP, Teissie J. Electrically-assisted nucleic acids delivery to tissues in vivo: where do we stand? Curr Pharm Des 2006; 12 : 3817-3825.

10 Mir LM. Nucleic acids electrotransfer-based gene therapy (electrogenetherapy): past, current, and future. Mol Biotechnol 2009; 43: 167-176.

11 Vidic S, Markelc B, Sersa G, Coer A, Kamensek U, Tevz G et al. MicroRNAs targeting mutant K-ras by electrotransfer inhibit human colorectal adenocarcinoma cell growth in vitro and in vivo. Cancer Gene Ther 2010; 17: 409-419.

12 Marshall Jr WG, Boone BA, Burgos JD, Gografe SI, Baldwin MK, Danielson ML et al. Electroporation-mediated delivery of a naked DNA plasmid expressing VEGF to the porcine heart enhances protein expression. Gene Therapy 2010; 17: 419-423.

13 Aung W, Hasegawa S, Koshikawa-Yano M, Obata T, Ikehira H, Furukawa T et al. Visualization of in vivo electroporation-mediated transgene expression in experimental tumors by optical and magnetic resonance imaging. Gene Therapy 2009; 16: 830-839.

14 Aihara H, Miyazaki J. Gene transfer into muscle by electroporation in vivo. Nat Biotechnol 1998; 16: 867-870.

15 Gehl J, Mir LM. Determination of optimal parameters for in vivo gene transfer by electroporation, using a rapid in vivo test for cell permeabilization. Biochem Biophys Res Commun 1999; 261: 377-380.

16 Gehl J, Sorensen TH, Nielsen K, Raskmark P, Nielsen SL, Skovsgaard T et al. In vivo electroporation of skeletal muscle: threshold, efficacy and relation to electric field distribution. Biochim Biophys Acta 1999; 1428: 233-240.

17 Lucas ML, Heller R. Immunomodulation by electrically enhanced delivery of plasmid DNA encoding IL-12 to murine skeletal muscle. Mol Ther 2001; 3: 47-53.

18 Mir LM, Bureau MF, Gehl J, Rangara R, Rouy D, Caillaud JM et al. High-efficiency gene transfer into skeletal muscle mediated by electric pulses. Proc Natl Acad Sci USA 1999; 96: 4262-4267.

19 Mir LM, Bureau MF, Rangara R, Schwartz B, Scherman D. Long-term, high level in vivo gene expression after electric pulse-mediated gene transfer into skeletal muscle. $C R$ Acad Sci III 1998; 321: 893-899.

20 Daud AI, DeConti RC, Andrews S, Urbas P, Riker AI, Sondak VK et al. Phase I trial of interleukin-12 plasmid electroporation in patients with metastatic melanoma. J Clin Oncol 2008; 26: 5896-5903.

21 Hojman P. Basic principles and clinical advancements of muscle electrotransfer. Curr Gene Ther 2010; 10: 128-138.

22 Burattini S, Ferri P, Battistelli M, Curci R, Luchetti F, Falcieri E. C2C12 murine myoblasts as a model of skeletal muscle development: morpho-functional characterization. Eur J Histochem 2004; 48: 223-233.

23 Cemazar M, Jarm T, Sersa G. Cancer electrogene therapy with interleukin-12. Curr Gene Ther 2010; 10: 300-311.

24 Heller LC, Heller R. Electroporation gene therapy preclinical and clinical trials for melanoma. Curr Gene Ther 2010; 10: 312-317.

25 Pavlin D, Cemazar M, Cör A, Sersa G, Pogacnik A, Tozon N. Electrogene therapy with interleukin-12 in canine mast cell tumors. Radiol Oncol 2011; 45: 30-39.

26 Bodles-Brakhop AM, Heller R, Draghia-Akli R. Electroporation for the delivery of DNAbased vaccines and immunotherapeutics: current clinical developments. Mol Ther 2009; 17: 585-592.

27 Andre F, Gehl J, Sersa G, Preat V, Hojman P, Eriksen J et al. Efficiency of high and low voltage pulse combinations for gene electrotransfer in muscle, liver, tumor and skin. Hum Gene Ther 2008; 19: 1261-1271.

28 Cemazar M, Golzio M, Sersa G, Hojman P, Kranjc S, Mesojednik S et al. Control by pulse parameters of DNA electrotransfer into solid tumors in mice. Gene Therapy 2009; 16: 635-644.

29 Tevz G, Pavlin D, Kamensek U, Kranjc S, Mesojednik S, Coer A et al. Gene electrotransfer into murine skeletal muscle: a systematic analysis of parameters for long-term gene expression. Technol Cancer Res Treat 2008; 7: 91-101.

30 Roos AK, Eriksson F, Walters DC, Pisa P, King AD. Optimization of skin electroporation in mice to increase tolerability of DNA vaccine delivery to patients. Mol Ther 2009; 17: 1637-1642.

31 Vry JD, Martinez-Martinez P, Losen M, Bode GH, Temel Y, Steckler T et al. Low currentdriven micro-electroporation allows efficient in vivo delivery of nonviral DNA into the adult mouse brain. Mol Ther 2010; 18: 1183-1191.

32 Hojman P, Gissel H, Andre FM, Cournil-Henrionnet C, Eriksen J, Gehl J et al. Physiological effects of high- and low-voltage pulse combinations for gene electrotransfer in muscle. Hum Gene Ther 2008; 19: 1249-1260.

33 Zupanic A, Corovic S, Miklavcic D, Pavlin M. Numerical optimization of gene electrotransfer into muscle tissue. Biomed Eng Online 2010; 9: 66.

34 Gabriel B, Teissie J. Control by electrical parameters of short- and long-term cell death resulting from electropermeabilization of Chinese hamster ovary cells. Biochim Biophys Acta 1995; 1266: 171-178.

35 Heller LC, Cruz YL, Ferraro B, Yang H, Heller R. Plasmid injection and application of electric pulses alter endogenous mRNA and protein expression in B16.F10 mouse melanomas. Cancer Gene Ther 2010; 17: 864-871.

36 Hojman P, Zibert JR, Gissel H, Eriksen J, Gehl J. Gene expression profiles in skeletal muscle after gene electrotransfer. BMC Mol Biol 2007; 8: 56

37 Rubenstrunk A, Mahfoudi A, Scherman D. Delivery of electric pulses for DNA electrotransfer to mouse muscle does not induce the expression of stress related genes. Cell Biol Toxicol 2004; 20: 25-31.

38 Bonnafous P, Vernhes M, Teissie J, Gabriel B. The generation of reactive-oxygen species associated with long-lasting pulse-induced electropermeabilisation of mammalian cells is based on a non-destructive alteration of the plasma membrane. Biochim Biophys Acta 1999; 1461: 123-134.

39 Gabriel B, Teissie J. Generation of reactive-oxygen species induced by electropermeabilization of Chinese hamster ovary cells and their consequence on cell viability. Eur J Biochem 1994; 223: 25-33.

40 Cooke MS, Evans MD, Dizdaroglu M, Lunec J. Oxidative DNA damage: mechanisms, mutation, and disease. FASEB J 2003; 17: 1195-1214.

41 Keller TJ, Oppenheimer NJ. Enhanced bleomycin-mediated damage of DNA opposite charged nicks. A model for bleomycin-directed double strand scission of DNA. J Biol Chem 1987; 262: 15144-15150.

42 Gabriel B, Teissie J. Spatial compartmentation and time resolution of photooxidation of a cell membrane probe in electropermeabilized Chinese hamster ovary cells. Eur J Biochem 1995; 228: 710-718.

43 Sabri N, Pelissier B, Teissie J. Electropermeabilization of intact maize cells induces an oxidative stress. Eur J Biochem 1996; 238: 737-743.

44 Shil P, Sanghvi SH, Vidyasagar PB, Mishra KP. Enhancement of radiation cytotoxicity in murine cancer cells by electroporation: in vitro and in vivo studies. J Environ Pathol Toxicol Oncol 2005; 24: 291-298.

45 Goldberg A, Rubinsky B. The effect of electroporation type pulsed electric fields on DNA in aqueous solution. Technol Cancer Res Treat 2010; 9: 423-430.

46 Faurie C, Rebersek M, Golzio M, Kanduser M, Escoffre JM, Pavlin M et al. Electromediated gene transfer and expression are controlled by the life-time of DNA/membrane complex formation. J Gene Med 2010; 12: 117-125.

47 Sabri N, Pelissier B, Teissie J. Ascorbate increases electrotransformation efficiency of intact maize cells. Anal Biochem 1998; 264: 284-286.

48 Wilcox CS, Pearlman A. Chemistry and antihypertensive effects of tempol and other nitroxides. Pharmacol Rev 2008; 60: 418-469.

49 Wilcox CS. Effects of tempol and redox-cycling nitroxides in models of oxidative stress. Pharmacol Ther 2010; 126: 119-145.

50 Mesojednik S, Pavlin D, Sersa G, Coer A, Kranjc S, Grosel A et al. The effect of the histological properties of tumors on transfection efficiency of electrically assisted gene delivery to solid tumors in mice. Gene Therapy 2007; 14: 1261-1269.

51 Tice RR, Agurell E, Anderson D, Burlinson B, Hartmann A, Kobayashi H et al. Single cell gel/comet assay: guidelines for in vitro and in vivo genetic toxicology testing. Environ Mol Mutagen 2000; 35: 206-221.

52 Collins AR, Duthie SJ, Dobson VL. Direct enzymic detection of endogenous oxidative base damage in human lymphocyte DNA. Carcinogenesis 1993; 14: 1733-1735.

53 Zegura B, Lah TT, Filipic M. The role of reactive oxygen species in microcystin-LRinduced DNA damage. Toxicology 2004; 200: 59-68.

54 Collins AR, Dusinska M, Gedik CM, Stetina R. Oxidative damage to DNA: do we have a reliable biomarker? Environ Health Perspect 1996; 104 (Suppl 3): 465-469.

55 Miklos M, Gajski G, Garaj-Vrhovac V. Usage of the standard and modified comet assay in assessment of DNA damage in human lymphocytes after exposure to ionizing radiation. Radiol Oncol 2009; 43: 97-107.

\section{(c)}

SOMER RIGHIS R

This work is licensed under the Creative Commons Attribution-NonCommercial-No Derivative Works 3.0

Unported License. To view a copy of this license, visit http:// creativecommons.org/licenses/by-nc-nd/3.0/ 